\title{
PLANTS OF THE ANNONACEAE TRADITIONALLY USED AS ANTIMALARIALS: A REVIEW ${ }^{1}$

\author{
GINA FRAUSIN ${ }^{2}$, RENATA BRAGA SOUZA LIMA ${ }^{3}$, \\ ARI DE FREITAS HIDALGO ${ }^{4}$, PAUL MAAS 5 , ADRIAN MARTIN POHLIT ${ }^{6}$
}

ABSTRACT- Species of the Annonaceae family are used all over the tropics in traditional medicine in tropical regions for the treatment of malaria and other illnesses. Phytochemical studies of this family have revealed chemical components which could offer new alternatives for the treatment and control of malaria. Searches in scientific reference sites (SciFinder Scholar, Scielo, PubMed, ScienceDirect and ISI Web of Science) and a bibliographic literature search for species of Annonaceae used traditionally to treat malaria and fever were carried out. This family contains 2,100 species in 123 genera. We encountered 113 articles reporting medicinal use of one or more species of this family including 63 species in 27 genera with uses as antimalarials and febrifuges. Even though the same species of Annonaceae are used by diverse ethnic groups, different plant parts are often chosen for applications, and diverse methods of preparation and treatment are used. The ethanol extracts of Polyalthia debilis and Xylopia aromatica proved to be quite active against Plasmodium falciparum in vitro (median inhibition concentration, $\mathrm{IC}_{50}<1.5 \mu \mathrm{g} / \mathrm{mL}$ ). Intraperitoneal injection of Annickia chlorantha aqueous extracts (cited as Enantia chlorantha) cleared chloroquine-resistant Plasmodium yoelii nigeriensis from the blood of mice in a dose-dependant manner. More phytochemical profiles of Annonaceous species are required; especially information on the more commonly distributed antimalarial compounds in this family.

Index terms: Malaria, Plasmodium falciparum, Plasmodium yoelii nigeriensis.

\section{PLANTAS DA FAMILIA ANNONACEAE TRADICIONALMENTE USADAS COMO ANTIMALÁRICOS: UMA REVISÃO}

RESUMO- Espécies da família Annonaceae têm amplo uso na medicina tradicional em regiões tropicais para o tratamento da malária e de sintomas como febres, dentre outras doenças. Estudos fitoquímicos desta família têm revelado componentes químicos que podem oferecer novas alternativas para o tratamento e controle da malária. Buscas em sites de referencia cientifica (SciFinder Scholar, Scielo, PubMed, ScienceDirect e ISI Web of Science) e uma pesquisa bibliográfica na literatura por espécies da família Annonaceae utilizadas tradicionalmente para tratar a malária e febre foram realizadas. Esta família contém 2.100 espécies em 123 gêneros. Encontramos 113 registros que relatam o uso de 63 espécies de 27 gêneros utilizadas como antimaláricos e febrifugas. Mesmo que as mesmas espécies de Annonaceae sejam utilizadas por diversos grupos étnicos, frequentemente diferentes partes da planta são escolhidas para o uso e diversos métodos de preparação e de tratamento são utilizados. Os extratos etanólicos de Polyalthia debilis e Xylopia aromatica são comprovadamente bastante ativos contra Plasmodium falciparum in vitro (concentração de inibição média, $\mathrm{IC}_{50}<1,5 \mu \mathrm{g} / \mathrm{mL}$ ). Injeção intraperitoneal de extratos aquosos de Annickia chlorantha (espécie citada Enantia chlorantha) eliminou Plasmodium yoelii nigeriensis cloroquino-resistente do sangue de camundongos de maneira dose-dependente. Mais perfis fitoquímicos de espécies de Annonaceae são necessários, especialmente informações sobre as substâncias antimaláricas mais comumente distribuídos nesta família.

Termos para indexação: Malária, Plasmodium falciparum, Plasmodium yoelii nigeriensis.

\footnotetext{
${ }^{1}$ (Trabalho 184-13) - Recebido em: 21-02-2013. Aceito para publicação em: 31-07-2013. V Congresso Internacional \& Encontro Brasileiro sobre Annonaceae: do gene à exportação (19 a 23 de Agosto).

${ }^{2}$ Research Network on Chemical Compounds from Plants of Ethnopharmacological Origin for Malaria Control in the States of Amazonas and Acre, Brazil/CNPq [Rede de Pesquisa de Compostos Químicos Vegetais para o Controle de Malária a partir da Etnofarmacologia nos Estados do Amazonas e Acre, Brasil/CNPq]. E-mail: ginafrausin@gmail.com

${ }^{3}$ Doctoral Fellow/Brazilian National Research Council (CNPq), Scholar, Graduate Program in Biotechnology, Federal University of Amazonas, Manaus, Amazonas State, Brazil. E-mail: renatabsl@hotmail.com

${ }^{4}$ Associate Professor, Federal University of Amazonas, Manaus, Amazonas State, Brazil. E-mail: afreitash@gmail.com

${ }^{5}$ Retired professor of Botany, Netherlands Centre for Biodiversity Natruralis. Biosystematics Group, Wageningen University, Generaal Foulkesweg 37,6703 BL Wageningen, the Netherlands. E-mail: paul.maas@wur.nl

${ }^{6}$ Senior Research Scientist and productivity in Research/ CNPq, Scholar at the National Institute for Amazon Research, Avenida André Araújo, 2936, Petró-polis, Caixa Postal 2223, CEP 69080-971, Manaus, Amazonas State, Brazil. E-mail: ampohlit@inpa.gov.br
} 


\section{INTRODUCTION}

Malaria and the Annonaceae family: The annual death of thousands of people worldwide due to malaria has made this disease one of the major problems in world health. This has motivated the development of research into new alternatives for the control and cure of this disease. Evidence for this is the diverse number of publications on screenings based on traditional medicine in Africa, India and South America regions where malaria is endemic and on the search for natural products derived from plants. Phytochemical studies are also important in this context for revealing natural products which may later be developed into new drugs. New antimalarials are needed because Plasmodium falciparum and $P$. vivax, the two main parasites responsible for malaria infections in humans, are becoming resistant to the two major classes of effective drugs, namely quinoline and artemisinin antimalarials. One of the main problems in malaria control is that this disease is endemic to generally poor and underdeveloped countries in tropical and subtropical regions of the world. These regions and their problems are not in general of major interest to the economically more developed countries. In this sense, part of the population which inhabits areas where malaria is endemic does not have access to efficient health services and sometimes the only source of therapeutic treatment is based on plants. Among the families which stand out due to their broad traditional uses against malaria is Annonaceae (order Magnoliales). This family is distributed pantropically and comprises approximately 123 genera and 2,100 species (MABBERLEY, 2008) of trees, shrubs and lianas. The antiprotozoal activity of Annonaceae species in traditional treatments of malaria, Chagas disease (American trypanosomiasis) and leishmaniasis is associated with secondary metabolite alkaloids, acetogenins, sterols and terpenes found in different parts of these plants (OCAMPO \& OCAMPO, 2006). This review covers ethnobotanic reports on Annonaceous species used traditionally to treat malaria and related symptoms (high and intermittent fevers, chills, headaches, body pain, liver ailments) and ethnopharmacologic studies demonstrating in vitro activity of extracts of plants of this family against Plasmodium falciparum (median inhibition concentrations, $\mathrm{IC}_{50}<1.5 \mu \mathrm{g} / \mathrm{mL}$ ) and other malaria parasites.

\section{MATERIAL AND METHODS}

Information on publications in the scientific literature was obtained using the SciFinder Scholar (2007) program and the input phrase "Antimalarials from Plants" which produced a list of publications from 1942 (first publication) to June, 2011. A list of 765 abstracts was initially obtained and further refined by restricting plants to the Annonaceae family. In similar fashion, references were found on the Scielo, PubMed, ScienceDirect and ISI Web of Science websites using the input phrase "antimalarials plants Annonaceae" in January, 2013 . Also, online searches were performed at different sites and at libraries at the Federal University of Amazonas in Manaus, Brazil, National Institute for Amazon Research in Manaus and University of La Amazonia in Colombia. The data were organized in a spreadsheet. Information registered in the spreadsheet included species names, geographical distribution, regions where the plant is used, preparation methods and parts of the plant used as antimalarials, as febrifuges, for headaches, liver problems, etc.. Also, where available, data on in vitro median inhibitory concentrations $\left(\mathrm{IC}_{50}\right)$ and in vivo activities against Plasmodium spp. used in literature studies were included.

\section{RESULTS AND DISCUSSION}

Traditional uses of Annonaceae: Different ethnic groups have used species of Annonaceae as a therapeutic source to combat malaria. While some species are not useful for the treatment of malaria per se they are used to treat the symptoms. In the present study, 63 species belonging to 27 genera were found in literature studies. In general, these plant species were used to treat the disease or its symptoms in countries in the Amazon region (northern South America); Africa, Central America, India and Malaysia (see Table 1). Eleven antimalarial species each for the genera Annona and Xylopia made these the most represented of the Annonaceae family. These genera have a pantropical distribution. They also are known to produce antimalarial alkaloids (FISCHER et al., 2004; GARAVITO et al., 2006).

The genus Annona: Well-known for its edible fruit. Annona muricata is the most widely used species worldwide in traditional medicine, as foodstuff and in the cosmetic industry. A. muricata 
was by far the most commonly cited Annonaceous plant for the treatment of malaria, fevers, liver ailments and headaches. Nineteen literature sources made reference to the use of roots, bark, fruit and leaves of this species in the preparation of therapeutic remedies among the peoples of India, Madagascar, Indonesia, Costa Rica, Barbados and a few countries from Africa and South America. Of the nineteen sources of literature reporting the use of A. muricata, twelve indicated use against fever and five reported specific use against malaria. The only reported use of this species for the curing of liver problems was by Hidalgo (2003) who observed the use of the bark of this species among the traditional riverine populations in the Brazilian Amazon. Also, populations along the Pacific coast of Colombia place leaves on the forehead of the sick person for the treatment of the headaches caused by malaria infections (BLAIR \& MADRIGAL, 2005). In Colombia, decoctions are prepared from fresh or dry leaves of $A$. muricata and drank to treat the feverish state brought on by malaria infections (GÓMEZESTRADA et al., 2011).

Annona squamosa: This species is known by the local name Sita phol and is cultivated in communities in Northeastern India. The fresh leaves of this plant are used together with Ocimum americanum and $O$. gratissimum (Lamiaceae) for the treatment of malaria in different communities found in Africa (KAOU et al., 2008). This species has other uses related to the control of malaria (and other insect-born diseases) such as repellency against Culicidae, Muscidae and Dictyoptera.

Xylopia: The medicinal properties and usefulness for the control of agricultural pests, mites, insects and nematodes of species of this genus have been studied (PONTES et al., 2007). Nine species are specifically used to treat malaria and two are used specifically to treat fevers among the local populations of Cameroon Colombia, Brazil, Peru and French Guiana. Generally, the fruit, bark and other aerial parts are used in the preparation of the traditional remedies made from plants of this genus. In Cameroon Xylopia aethiopica, commonly named Ethiopian Pepper is the only species of this genus claimed to be useful for the treatment of malaria and other diseases. For treatment of malaria, a decoction is prepared from a teaspoon of bark crushed in a liter of water and then drank. For the treatment of fevers, the same procedure is applied to the dry fruit (TSABANG et al., 2011). Also against fever, Grenand et al. (1987) reported the use of Xylopia frutescens among the Wayãpi Indians of French Guiana. Xylopia aromatica is also reported to be useful for the treatment of malaria by local populations in the region around the Brazilian Federal Capital, Brasília (MESQUITA et al., 2007).

Other genera: 43 additional species representing 23 genera of Annonaceae have been reported in the literature for the treatment of fevers, malaria and headaches, although none of these were indicated for the treatment of liver problems related to malaria. In the Colombian Amazon region, the Tikuna use a decoction of the bark of Cymbopetalum brasiliense for the treatment of fevers (SCHULTES \& RAFFAUF, 1994) and a decoction of the external bark of Duguetia duckei is used by Tiriyó communities in the Brazilian state of Pará (CAVALCANTE \& FRIKEL, 1973). Guatteria discolor bark is used in a bath among the Wayãpi Indians of French Guiana for the same purpose (GRENAND et al., 1987). Schultes and Raffauf (1994) reported the use of the bark of Guatteria schunkevigoi among the local populations in the Napo region of Ecuador. In the procedure described, the bark is ground and mixed with water and rubbed on the body to combat fevers. The same method is used for the preparation of Guatteria discolor among the Wayãpi populations in French Guiana, though in this case the Wayãpi decoct the bark (GRENAND et al., 1987). In Cameroon, a decoction of the stem bark (500 g) of Duguetia staudtii obtained by scraping the bark with a large knife, or leaves $(100 \mathrm{~g})$ soaked in water for $20 \mathrm{~min}$ are used in the preparation of a drink which is taken to treat headaches. Similarly, a decoction of leaves $(100 \mathrm{~g})$ in water (3 L, $20 \mathrm{~min})$ is used for bathing the head (TSABANG et al., 2011). Desmos teijsmanii and Monodora tenuifolia are used to treat similar aches in Malaysia and Cameroon, respectively (KULIP, 2003; TSABANG et al., 2011).

\section{Preparations and plant parts utilized in} traditional remedies: Different plant parts and methods of preparation are utilized in traditional therapies involving Annonaceous plants. Some methods of preparation are reported more frequently than others. Also, some authors do not provide 
information on the methods of preparation. Other authors provide varying degrees of information on these preparations. Most of the sources consulted presented information on preparations involving plant materials that were vague regarding the dosages and the duration of the treatment involving Annonaceae-derived botanicals. The bark is the part of Annonaceae plants which is most often reported in the literature containing descriptions of the preparation of traditional remedies, followed by the leaves and then fruit. The seeds and roots were cited only twice each as being used for remedies. Flowers were used in only one preparation, that involving Cananga odorata, for the treatment of malaria infections. Infusions and decoctions are the methods of preparation of the remedies used in the most common treatments. Administration by mouth is by far the most common route used for Annonaceae traditional remedies.

Lannuzel et al. (2002) suggest that alkaloids from $A$. muricata can modulate the function and the survival of dopaminergic nerve cells in vitro. There are indications that annonacine, found in large quantities in A. muricata, can diminish the levels of ATP in (mesencephalic-derived) dopaminergic cells of rat embryos (LANNUZEL et al., 2003).

Some traditional formulations of Annonaceae plants involve the addition of other plant species. Thus, the roots of Annona muricata are boiled together with those of Blumea balsamifera (Asteraceae), Cymbopogon citratus and Imperata cylindrica (Poaceae) and the aromatic vapor is used to heat the body of people who suffer from high fevers in kadazandusun communities in Malaysia (FASIHUDDIN \& GHAZALLY, 2003). Topical applications in the form of baths, although less frequently used, are advised for the treatment of fevers and headaches (as indicated above). Another form of treatment involves the vapours of baths with Annona ambotay and $A$. haematantha (GRENAND et al., 1987). In French Guiana, the Wayãpi Indians use Annona ambotay leaves and bark crushed, grated and rubbed on the body. They also boiled this plant in a pot and placed the boiled mixture beneath a hammock as vapour bath for the treatment of fever (GRENAND et al., 1987).
Chemical diversity of Annonaceae and scientific evidence for antimalarial activity: The Annonaceae exhibit important biological activity in general. Many different secondary metabolites have been reported in Annonaceae. These include acetogenins, sterols, sesquiterpene lactones, quinones and alkaloids. In the literature, one finds reports on the use of plants of this family against diseases such as cancer (OBERLIES et al., 1997). In Table 2 , the results of studies on the in vitro activity of Annonaceous plant extracts against Plasmodium falciparum are summarized. Active extracts $\left(\mathrm{IC}_{50}\right.$ $<5 \mu \mathrm{g} / \mathrm{mL}$ ) from the following species have been described: Annona coriacea $\left(\mathrm{IC}_{50}=4.4 \mu \mathrm{g} / \mathrm{mL}\right)$; Hexalobus crispiflorus $\left(\mathrm{IC}_{50}=2.0 \mu \mathrm{g} / \mathrm{mL}\right)$; Polyalthia debilis $\left(\mathrm{IC}_{50}=1.4 \mu \mathrm{g} / \mathrm{mL}\right)$; Uvariopsis congensis $\left(\mathrm{IC}_{50}=2.8 \mu \mathrm{g} / \mathrm{mL}\right) ;$ Xylopia aromatica $\left(\mathrm{IC}_{50}<1 \mu \mathrm{g} /\right.$ $\mathrm{mL})$ and Xylopia emarginata $\left(\mathrm{IC}_{50}=3.3 \mu \mathrm{g} / \mathrm{mL}\right)$ (Table 2). Fischer et al. (2004) reported the in vitro antimalarial activity of crude extracts and alkaloidcontaining fractions from six species of Annonaceae (Annona coriacea, Duguetia lanceolata, Duguetia furfuracea, Guatteria australis, Xylopia brasiliensis and Xylopia emarginata) (Table 2). The most active antimalarial fractions $\left(\mathrm{IC}_{50}<5 \mu \mathrm{g} / \mathrm{mL}\right.$ ) were those of Annona coriacea $\left(\mathrm{IC}_{50}=1.6 \mu \mathrm{g} / \mathrm{mL}\right.$, against the $\mathrm{K} 1$ strain of $P$. falciparum $),$ Duguetia lanceolata $\left(\mathrm{IC}_{50}=\right.$ 2 and $5 \mu \mathrm{g} / \mathrm{mL}$, against the $\mathrm{K} 1$ and Palo Alto strains of P. falciparum, respectively), Duguetia furfuracea $\left(\mathrm{IC}_{50}=4.8 \mu \mathrm{g} / \mathrm{mL}\right.$, against the Palo Alto strain of $P$. falciparum) and Guatteria australis $\left(\mathrm{IC}_{50}=0.3\right.$ and $1.8 \mu \mathrm{g} / \mathrm{mL}$, against the $\mathrm{K} 1$ and Palo Alto strains of P. falciparum, respectively).

The in vitro antimalarial activity of essential oils (Table 2) has been attributed to sesquiterpenes which are among the major components. Boyom et al. (2003) reported that the essential oil obtained from the bark of Duguetia confine (cited as Pachypodanthium confine) was approximately $88 \%$ sesquiterpenes and $0.64 \%$ aromatic substances. Also, these authors found that the essential oil obtained from the bark of Xylopia aethiopica contained ca. $45 \%$ sesquiterpenes and the essential oil extracted from the bark of Xylopia phloiodora contained approximately $88 \%$ sesquiterpenes and 3\% aromatic compounds. The essential oil of Cleistopholis patens contained 81\% sesquiterpenes and the major components of the bark essential oil were: a-copaene, d-cadinene, and germacrene $\mathrm{D}$; the major components of the leaf essential oil were: b-caryophyllene, germacrene D, 
and germacrene B (BOYOM et al., 2011). The genus Uvaria has undergone extensive study related to its in vitro antimalarial activity making it arguably the most studied among Annonaceae genera for this kind of biological activity (Table 1). Nkunya et al. (1991) described a study of nine species of Uvaria in which the following antimalarial substances were isolated: uvaretin, diuvaretin and (8',9'-dihydroxy)3-farnesylindole $\left(\mathrm{IC}_{50}=3.5,4.2\right.$ and $2.7 \mu \mathrm{g} / \mathrm{mL}$, respectively, against the $\mathrm{K} 1$ strain of $P$. falciparum. In their review on natural products from traditionally used antimalarial plants, Bero and Quetin-Leclercq (2011) reported that the antiplasmodial substance (+)-3-acetylaltholactone was isolated from the extracts of the flowers of Goniothalamus laoticus Bân and exhibited in vitro activity against the K1 strain of P. falciparum ( IC $_{50}=9.5 \mu \mathrm{M}$ ). In vivo activity was observed for another Annonaceous species, Annickia chlorantha (cited as Enantia chlorantha), which is found in Nigeria and other parts of West Africa. The aqueous extracts of this plant were administered intraperitoneally and cleared chloroquine-resistant $P$. yoelii nigeriensis infections from the blood of albino mice in a dose-dependant manner (KIMBI E FAGBENRO-BEYIOKU, 1996).

Geographic distribution: The reports on the use of Annonaceae for combatting malaria infections and symptoms of this disease are all from pantropical areas and are obviously the fruit of local experiences in countries where malaria is endemic. Most of the reports available are concentrated in traditional populations of South America and some African countries. The use of species of Annonaceae and other families is directly related to their natural distribution. One example is species of the genus Annona. These species are now found throughout the tropics and are used by peoples in Africa, Central and South America, India and several Caribbean countries. Another example is species of Xylopia used among the populations of Brazil, Cameroon, Colombia, French Guiana, Peru, and Togo. Interestingly, the genus Guatteria has a Neotropical distribution and is restricted in use to traditional populations in the Amazonian regions of Brazil, Colombia, Ecuador and Guyana. In Brazil in particular, there is a broad use of plants from the Annonaceae represented by seven species in five genera. Overall, the genus Annona is represented by ten species and is by far the most important antimalarial genus of this family. 


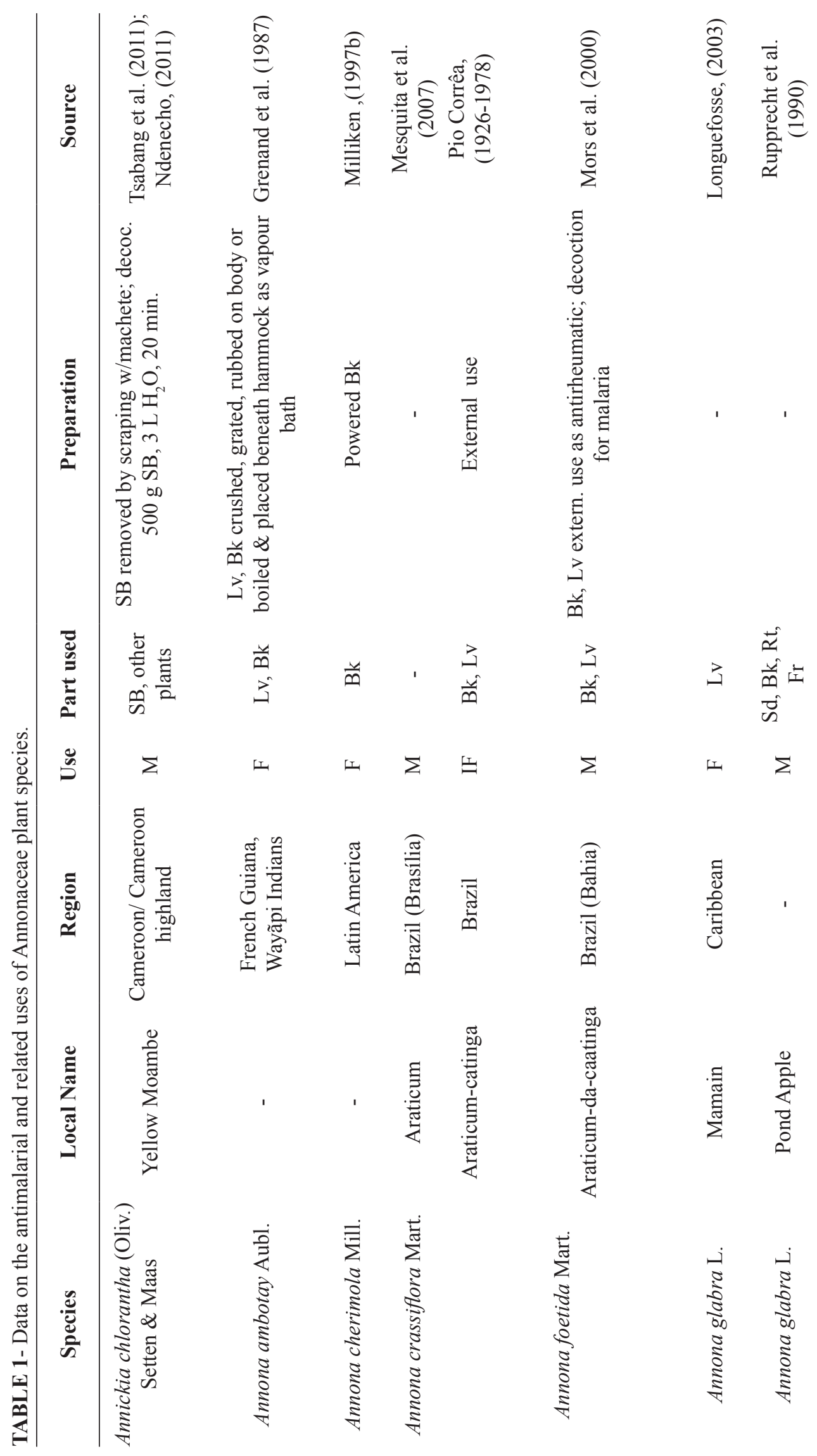




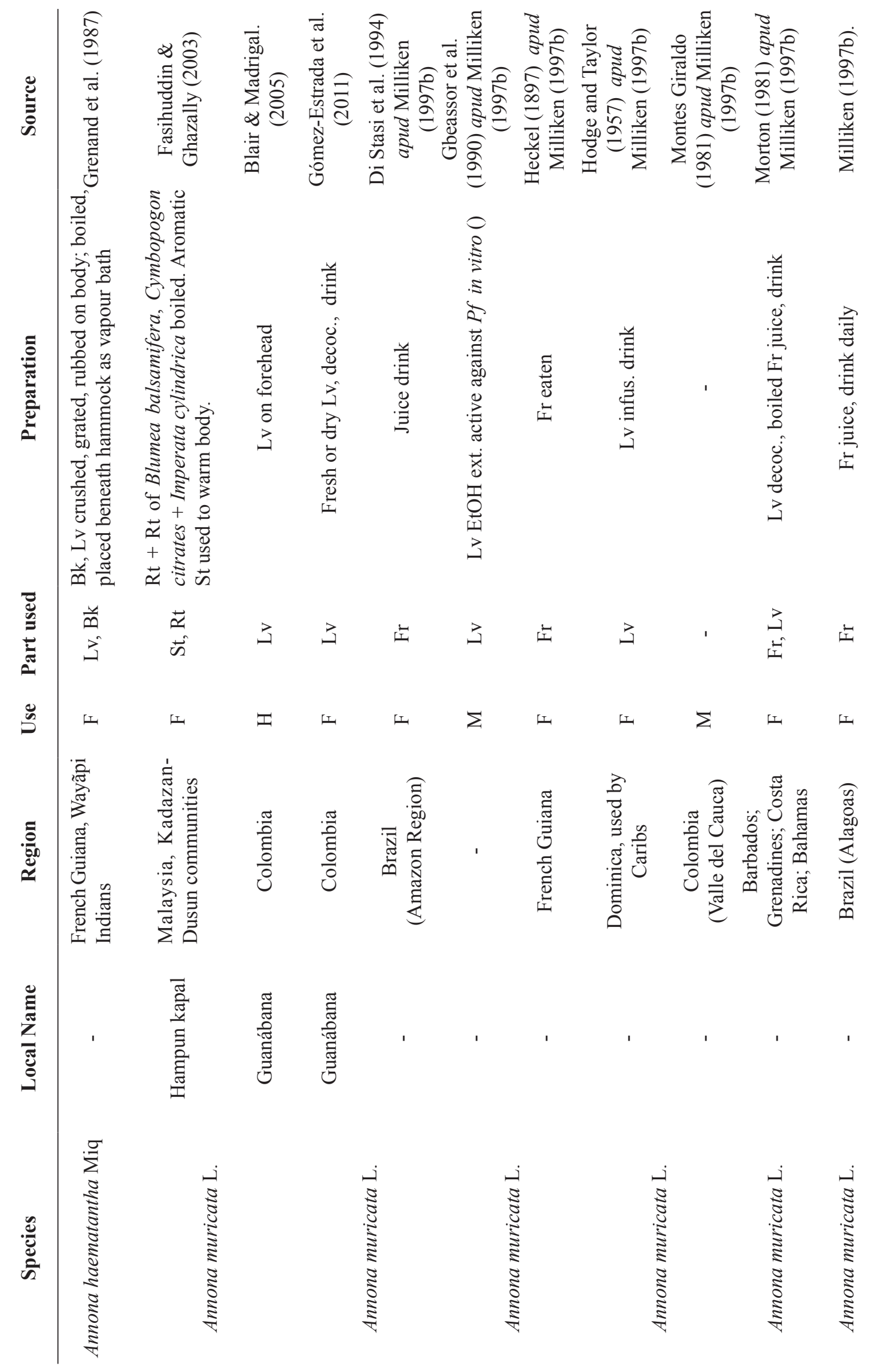




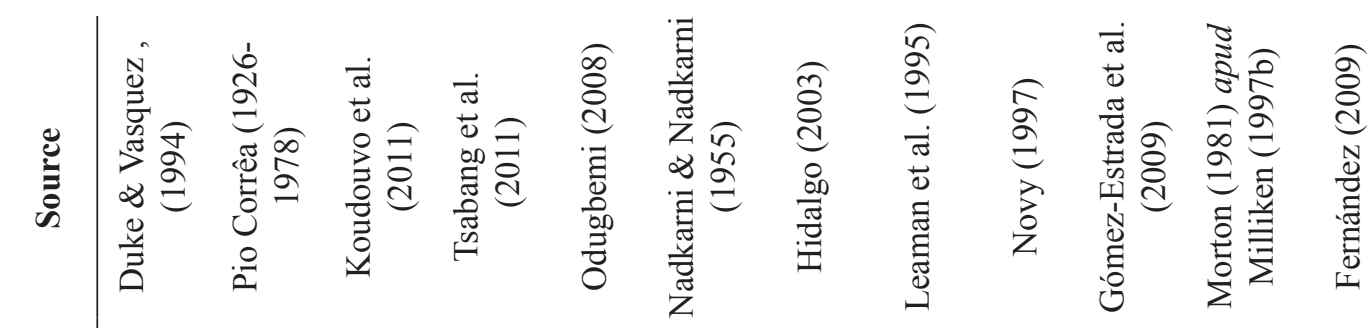

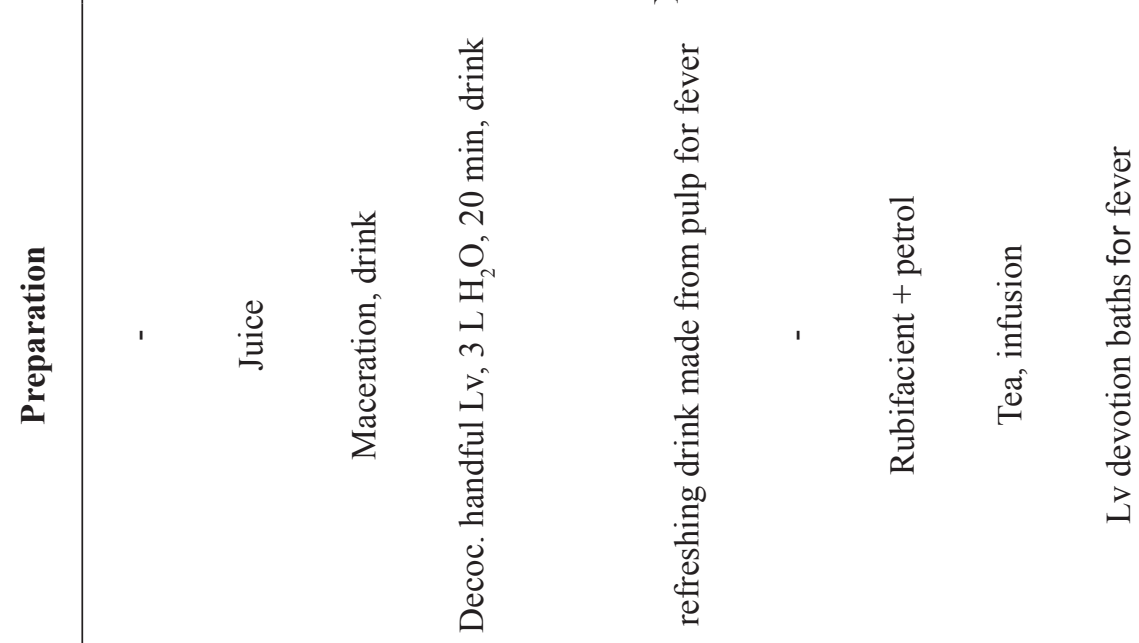

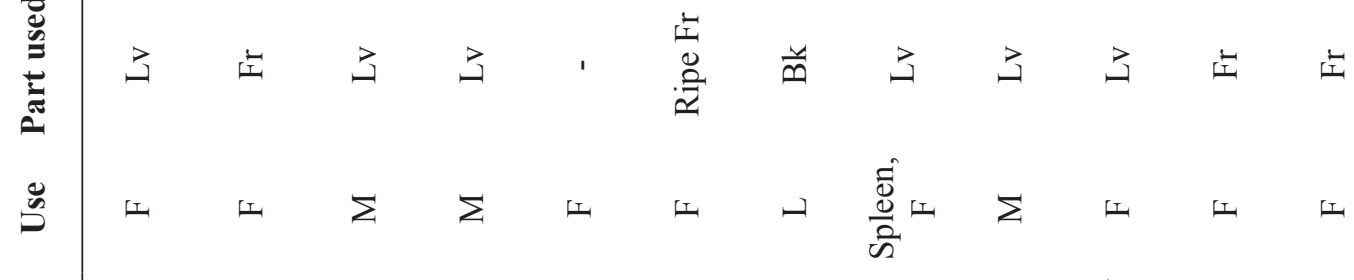

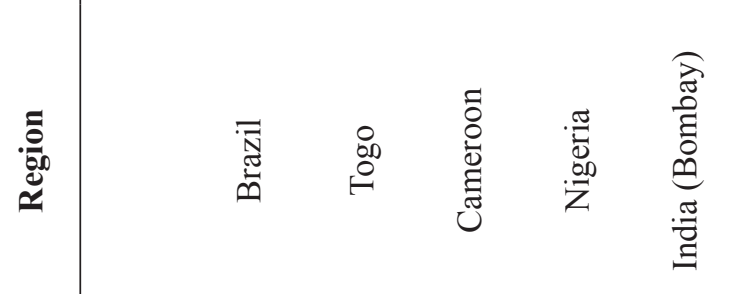

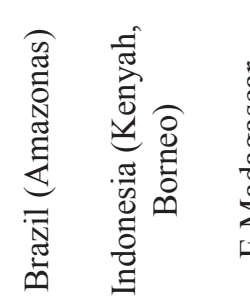

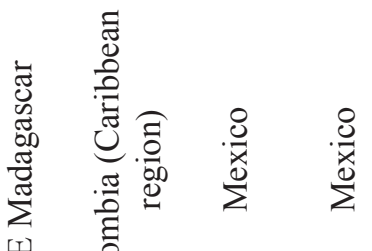

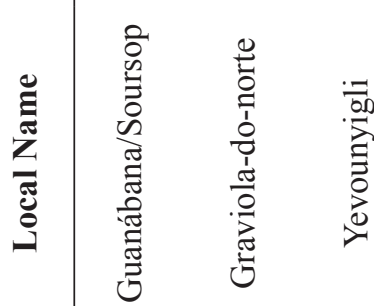

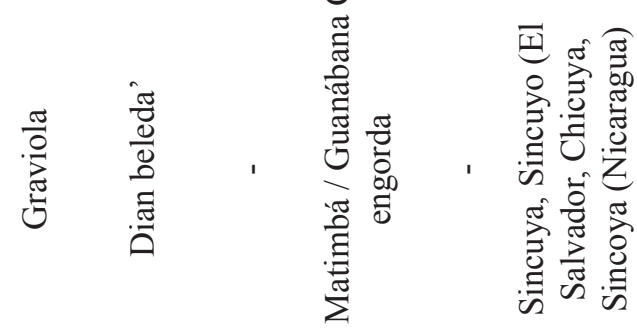

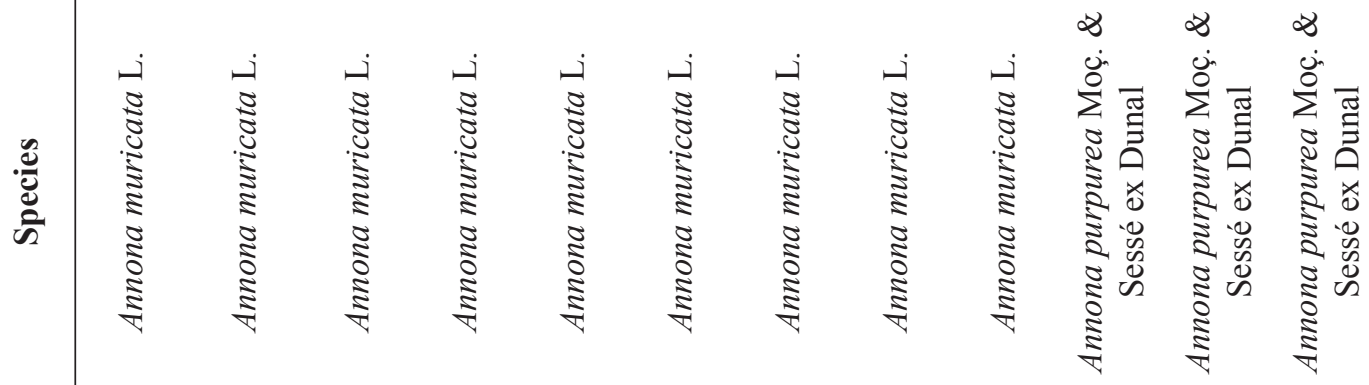




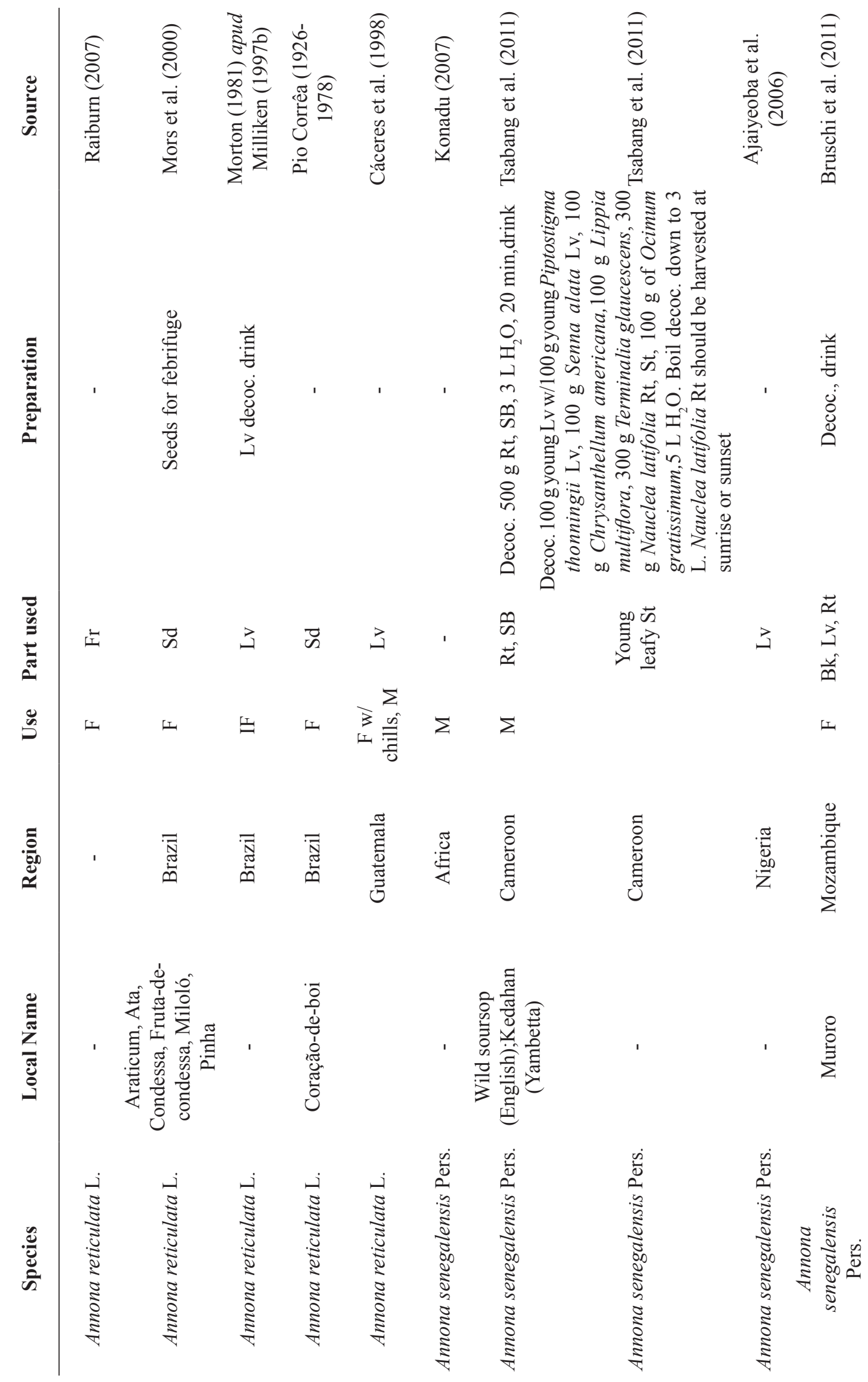



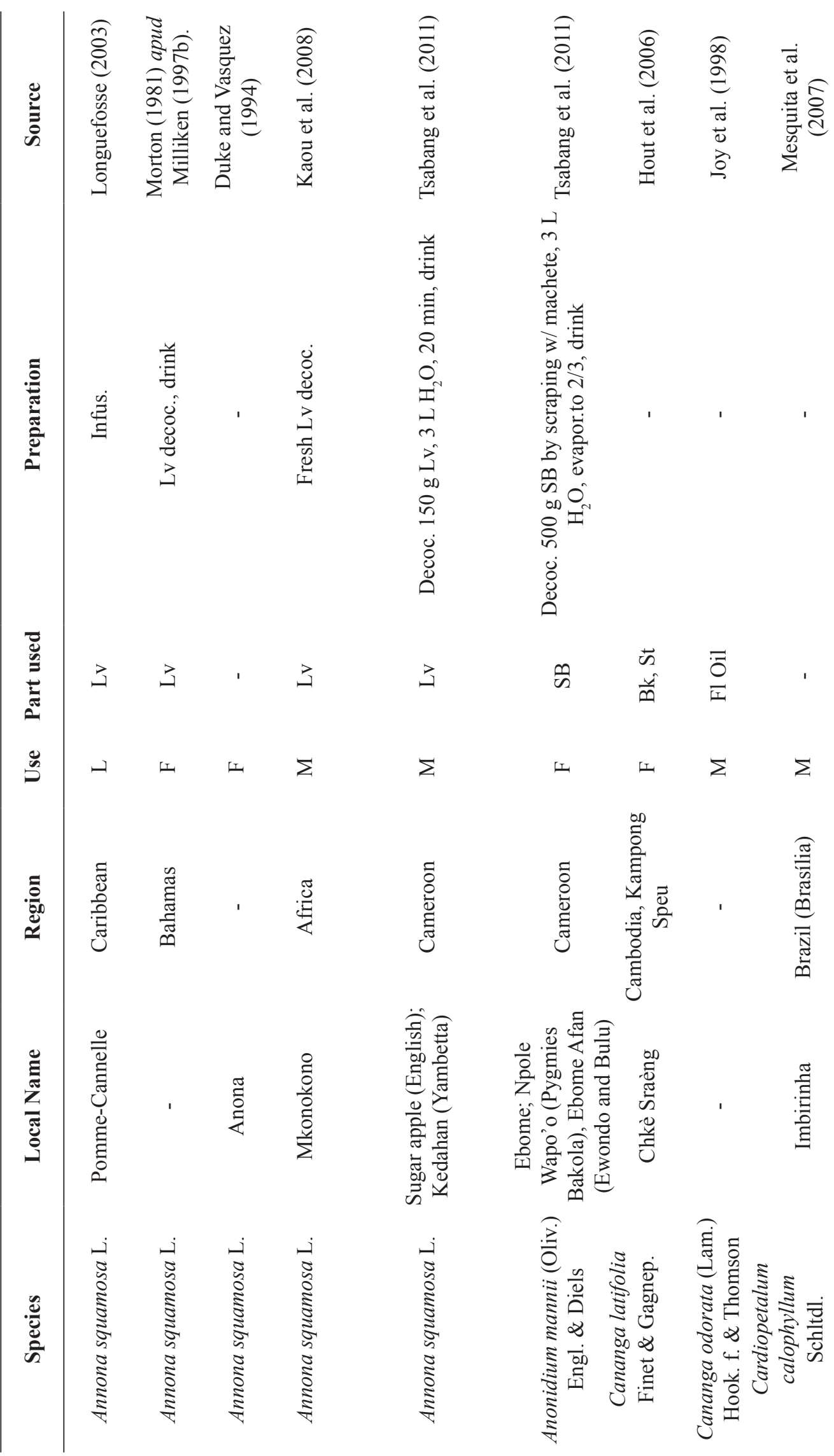


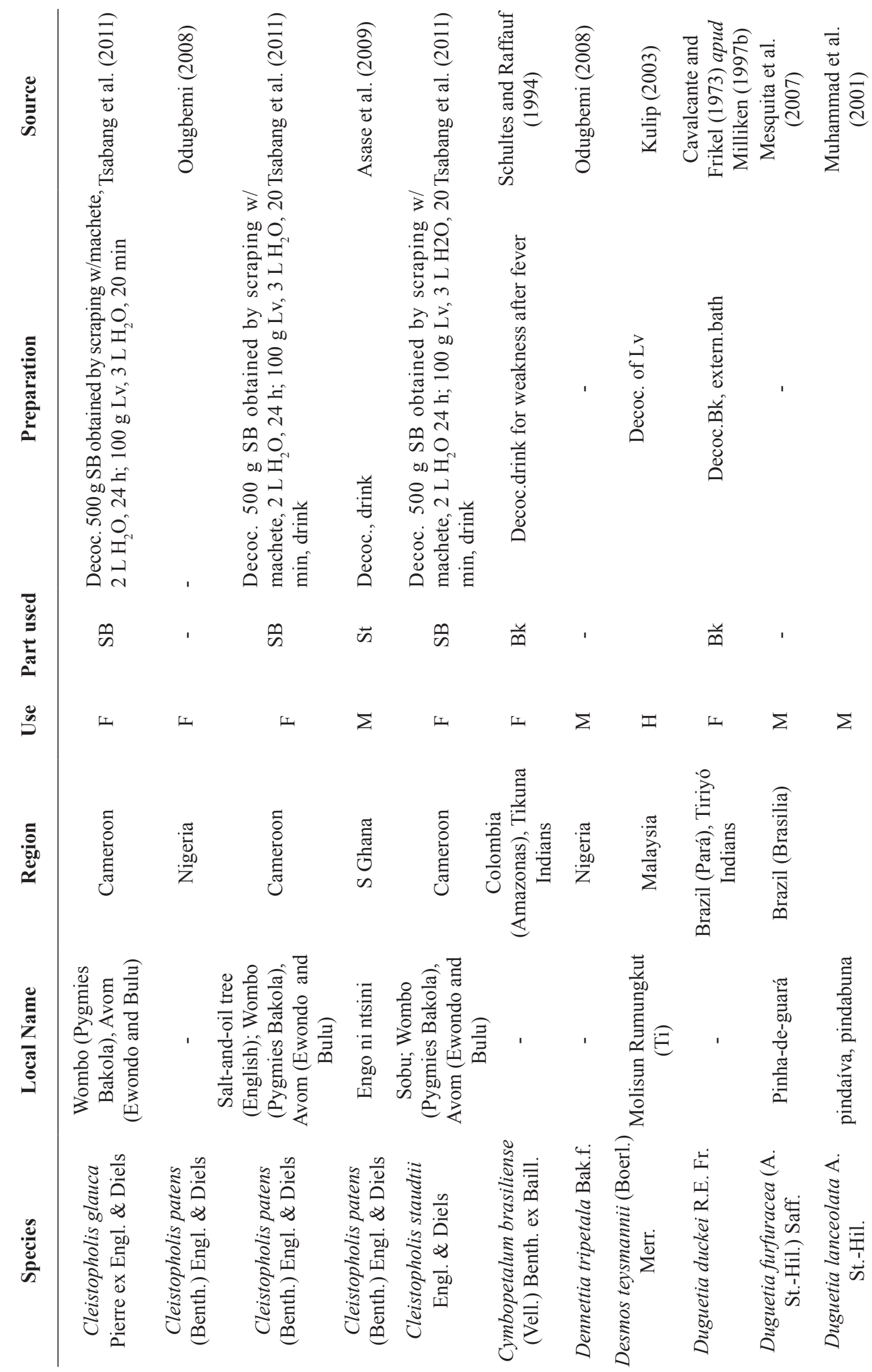




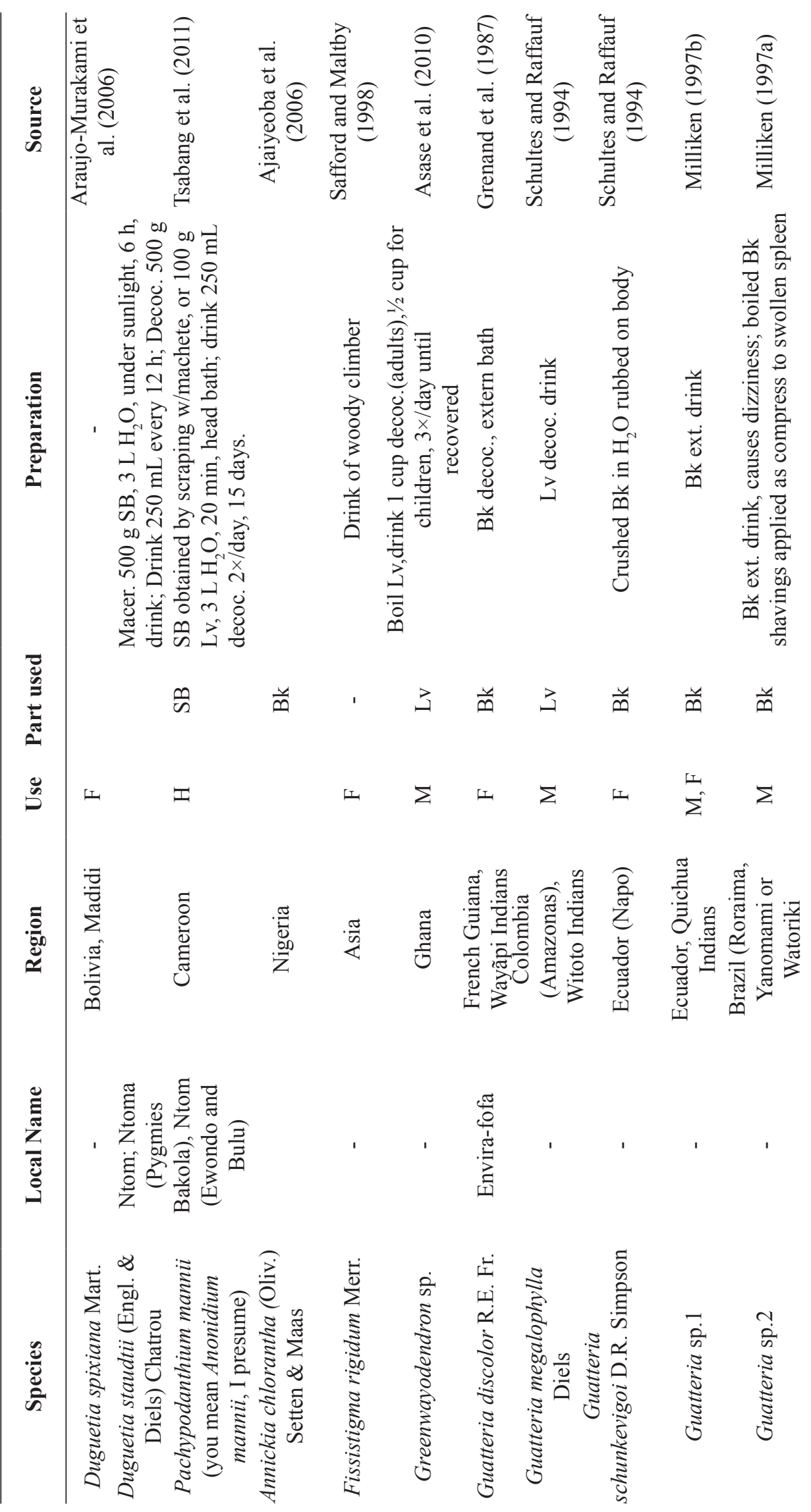




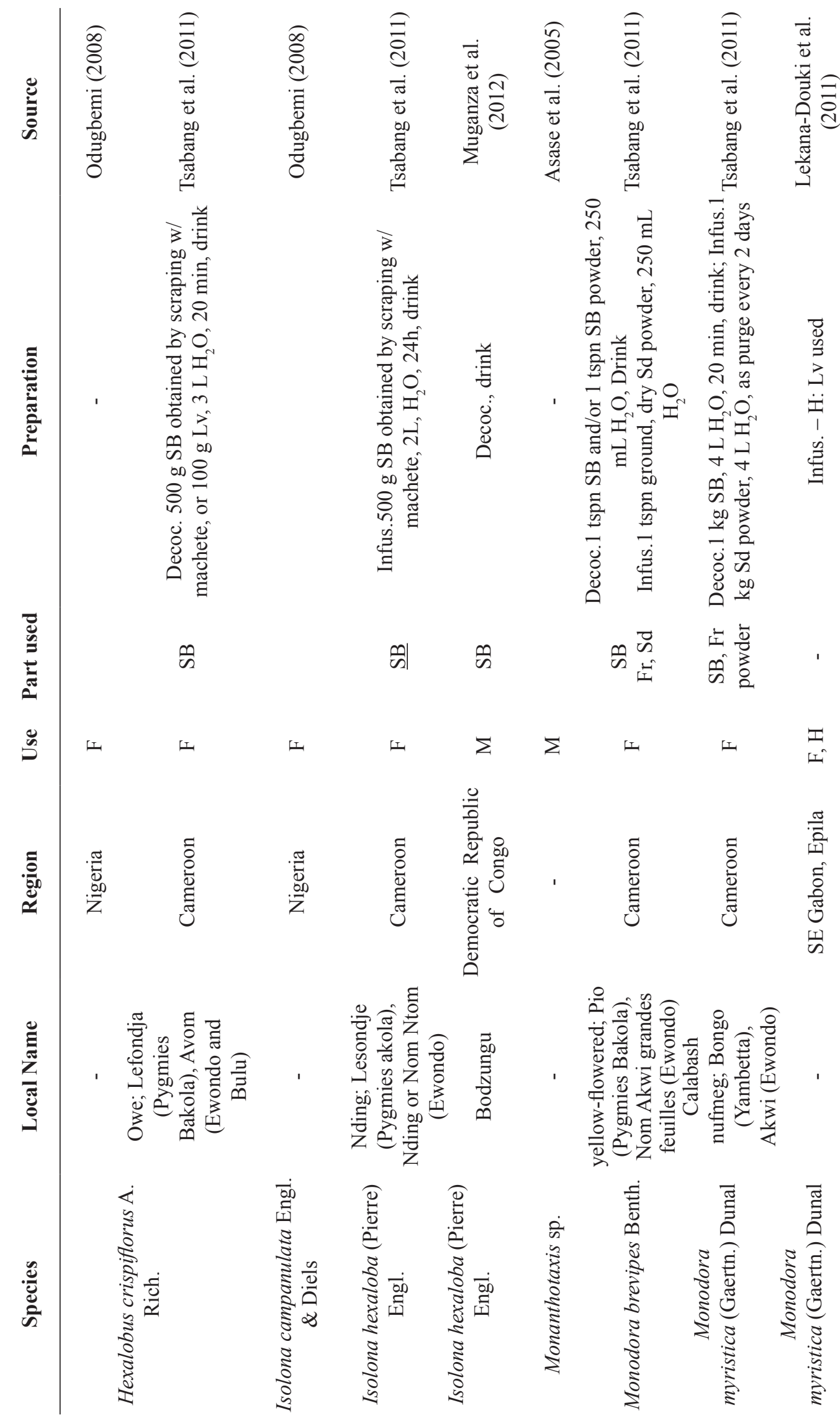



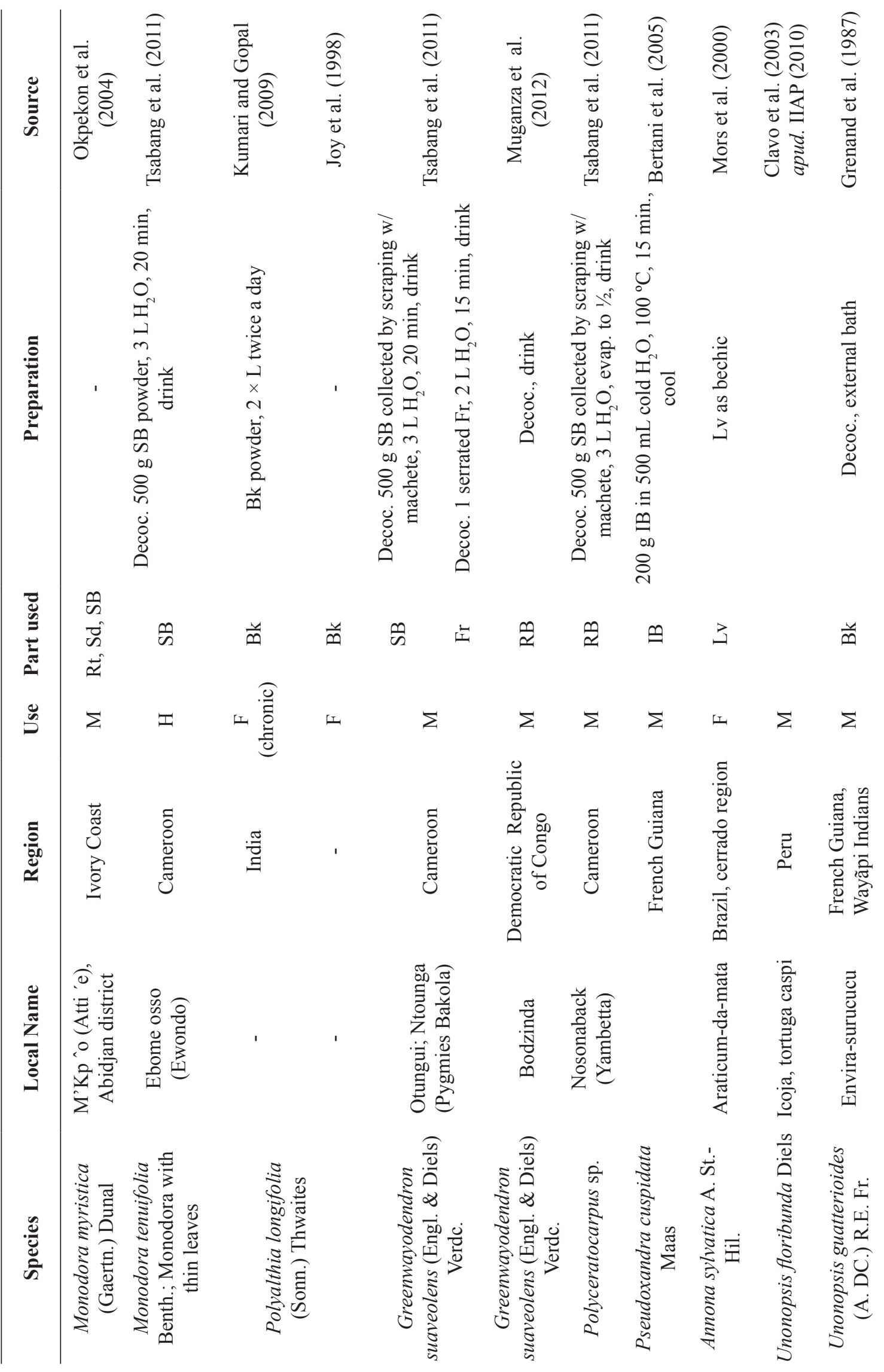


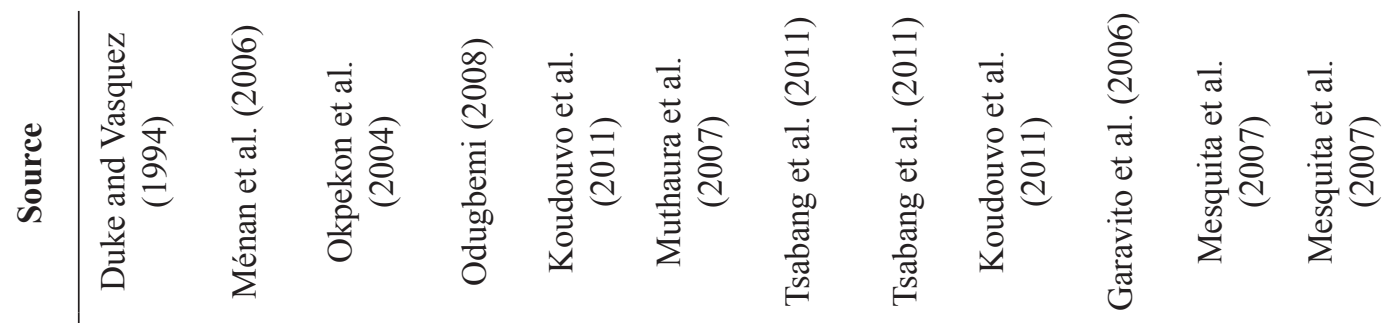

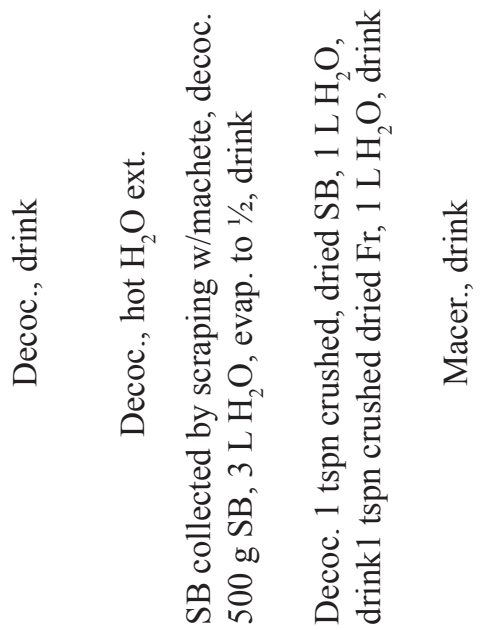

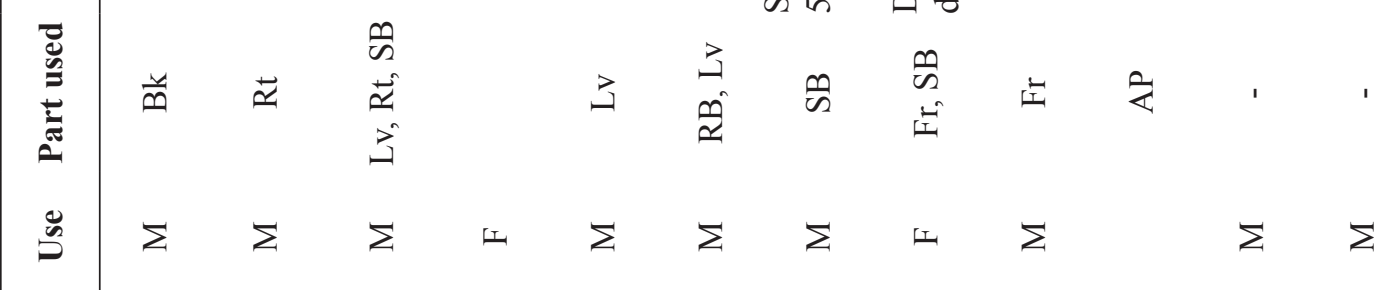

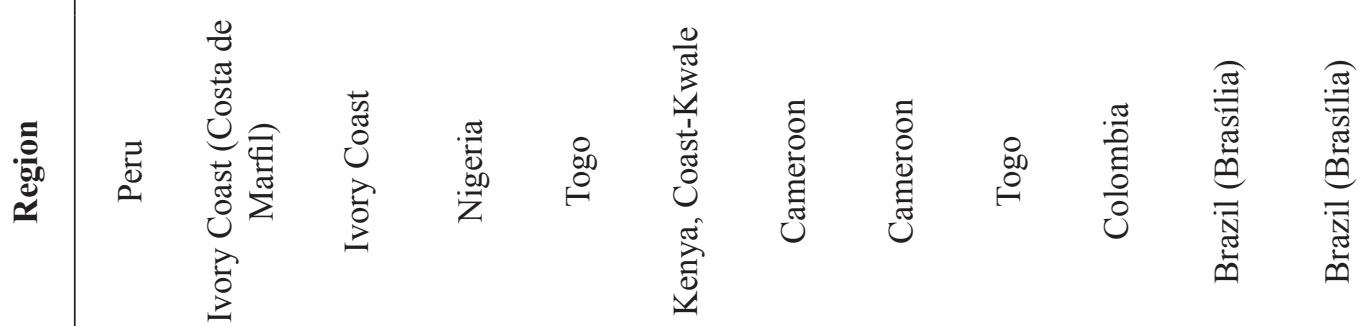

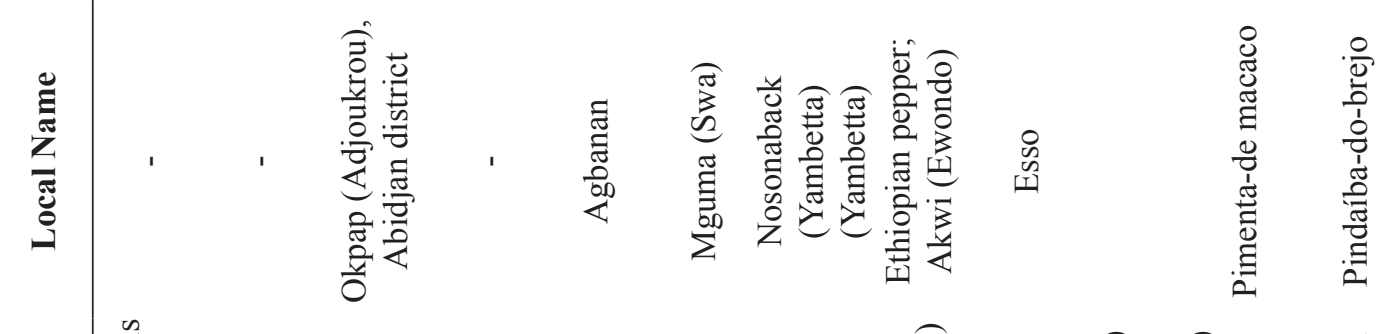

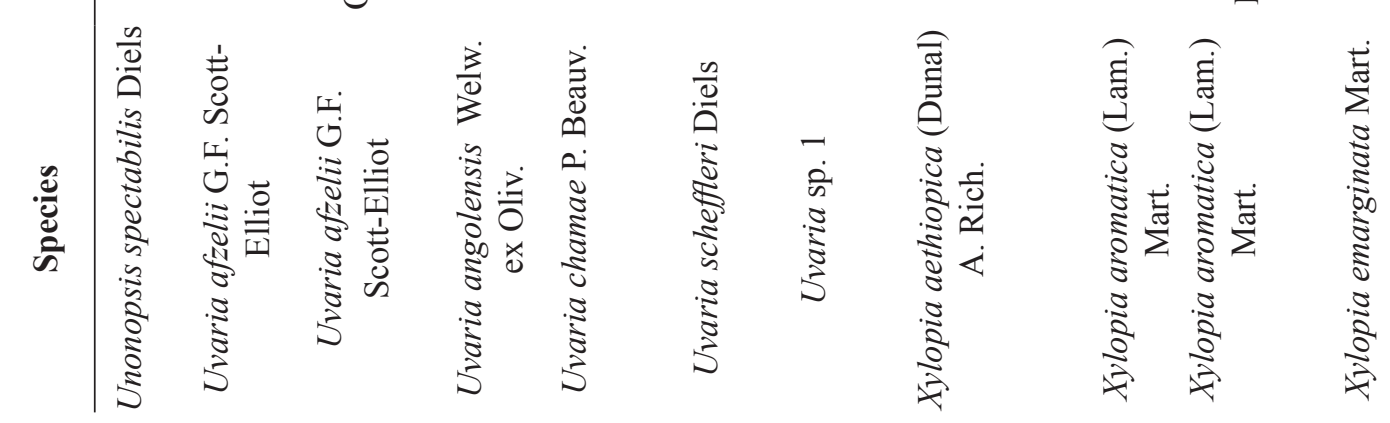




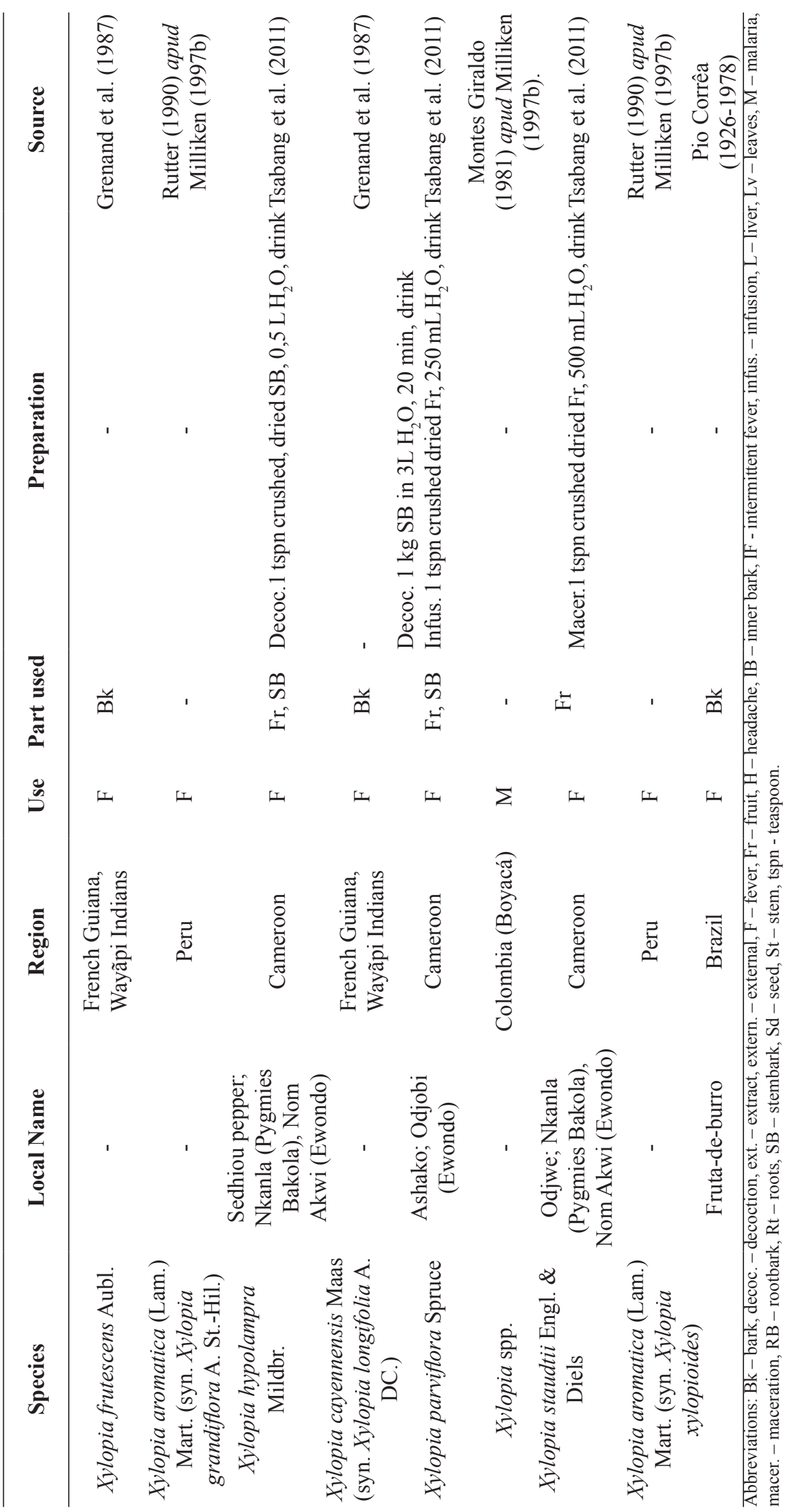




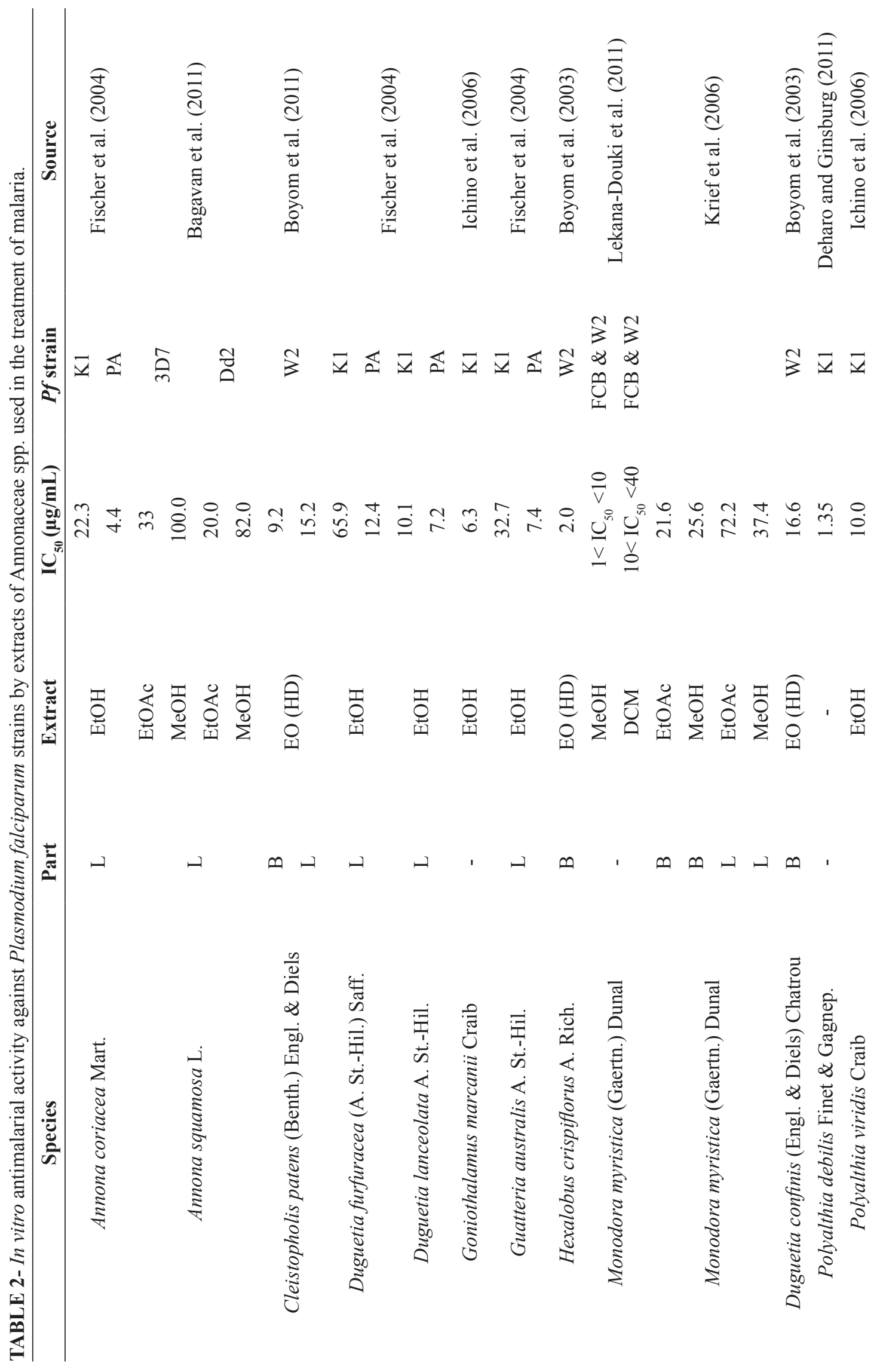




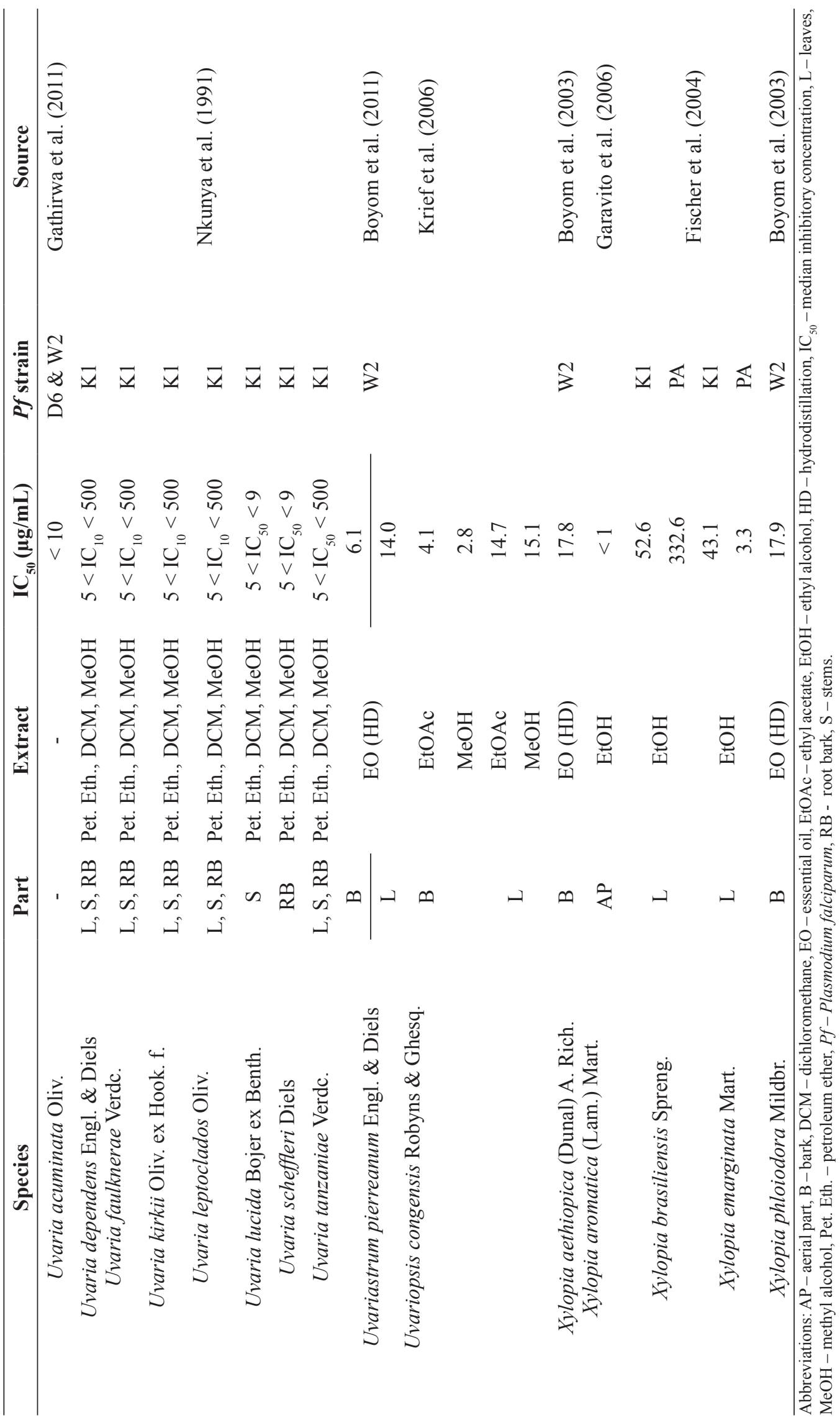




\section{CONCLUSION}

The Annonaceae family is rich in potential as a source of chemical entities for the development of novel antimalarial drugs. Several species belonging to this family have been well studied and have provided active antimalarial substances. On the other hand, a large number of species traditionally used to treat malaria from this family have not been studied so far, thus no chemical or pharmacological data are available. Intensification of research in the area of natural products chemistry together with screening for antimalarial activity could provide the lead compounds necessary for new drug development, a result which is awaited by the populations of endemic areas all over the world.

\section{ACKNOWLEDGEMENTS}

The authors thank the Herbarium at the Universidade de La Amazonia in Colombia for the use of bibliographic materials. Funding was provided by grants from the Brazilian National Council for Scientific and Technological Development (CNPQ, National Malaria Network and Bionorth Program), the Amazonas State Research Support Foundation (FAPEAM, PRONEX). G. F., R. B. S. L. and A. M. P. would like to recognize the following scholarships received from CNPq: DTI, GD (383557/2010$0),(554317 / 2010-9)$ and PQ (311.649/2011-4), respectively.

\section{REFERENCES}

AJAIYEOBA, E.O.; ABIODUN O.O.; FALADE, M.O; OGBOLE N.O.; ASHIDI, J.S.; HAPPI, C.T.; AKINBOYE, D.O. In vitro cytotoxicity studies of 20 plants used in Nigerian antimalarial ethnomedicine. Phytomedicine, Chicago, v.13, p.295-298, 2006.

ARAUJO-MURAKAMI, A.; ZENTENO RUIZ, F.S. Bosques de los Andes orientales de Bolivia y sus especies útiles. In: MORAES, M.R.; ØLLGAARD, B.; KVIST, L.P.; BORCHSENIUS, F.; BALSLEV, H. (Ed.). Botánica económica de los Andes Centrales. La Paz: Universidad Mayor de San Andrés, 2006. p. 146-161.

ASASE, A.; AKWETEY, G.A.; ACHEL, D.G. Ethnopharmacological use of herbal remedies for the treatment of malaria in the Dangme West District of Ghana. Journal of Ethnopharmacology, Limerick, v.129, p.367-376, 2010.
ASASE, A.; OPPONG-MENSAH, G. Traditional antimalarial phytotherapy remedies in herbal markets in southern Ghana. Journal of Ethnopharmacology, Limerick, v.126, p.492-499, 2009.

ASASE,A.; OTENG-YEBOAH,A.A.; ODAMTTEN, G.T.; SIMMONDS, M.S.J. Ethnobotanical study of some Ghanaian antimalarial plants. Journal of Ethnopharmacology, Limerick, v.99, p.273-279, 2005 .

BAGAVAN, A.; RAHUMAN, A.A.; KAUSHIK, N.K.; SAHAL, D. In vitro antimalarial activity of medicinal plant extracts against Plasmodium falciparum. Parasitology Research, New York, v.108, n.1, p.15-22, 2011.

BERO, J.; QUETIN-LECLERCQ, J. Natural products published in 2009 from plants traditionally used to treat malaria. Planta Medica, Antwerp, v.77, n.6, p.631-640, 2011.

BERTANI, S.; BOURDY, G.; LANDAU, I.; ROBINSON, J.C.; ESTERRE, P.H.; DEHARO, E. Evaluation of French Guiana traditional antimalarial remedies. Journal of Ethnopharmacology, Limerick, v.98, p.45-54, 2005.

BLAIR, S.; MADRIGAL, B. Plantas antimaláricas de Tumaco: Costa Pacífica Colombiana. Medellín: Editorial Universidad de Antioquia, 2005. p.266-270.

BOYOM, F.F.; NGOUANA, V.; KEMGNE, E.A.M.; ZOLLO, P.H.A.; MENUT, C.; BESSIERE, J.M.; GUT, J.; ROSENTHAL, P.J. Antiplasmodial volatile extracts from Cleistopholis patens Engler \& Diels and Uvariastrum pierreanum Engl. \& Diels (Annonaceae) growing in Cameroon. Parasitology Research, New York, v.108, n.5, p.1211-1217, 2011.

BOYOM, F.F.; NGOUANA, V.; ZOLLO, P.H.A.; MENUT, C.; BESSIÈRE, J.M.; GUT, J.; ROSENTHAL, P.J. Composition and antiplasmodial activities of essential oils from some Cameroonian medicinal plants. Phytochemistry, Oxford, v.64, n.7, p.1269-1275, 2003.

BRUSCHI, P.; MORGANTI, M.; MANCINI, M.; SIGNORINI, M.A. Traditional healers and lay people: A qualitative and quantitative approach to local knowledge on medicinal plants in Muda (Mozambique). Journal of Ethnopharmacology, Limerick, v.138, p.543- 563, 2011. 
CÁCERES, A.; LÓPEZ, B.; GONZÁLEZ, S.; BERGER, I.; TADA, I.; MAKI, J. Plants used in Guatemala for the treatment of protozoal infections. I. Screening of activity to bacteria, fungi and American trypanosomes of 13 native plants. Journal of Ethnopharmacology, Limerick, v.62, p.195-202, 1998.

CAVALCANTE, P.B.; FRIKEL, P. A farmacopeia Tiriypó. MPEG, Bélem. 1973 apud MILLIKEN, 1997b.

CLAVO, P.; ZOYLA, M.; SEIJAS, C.; ZULLY, P.; ALEGRE, O.J. Plantas medicinales: usadas por mujeres nativas y mestizas en la Región Ucayali. Pucallpa, 2003. p.124 apud IIAP -Instituto de Investigaciones de La Amazonía Peruana. Base de datos plantas medicinales, 2010.

DEHARO, E.; GINSBURG, H. Analysis of additivity and synergism in the anti-plasmodial effect of purified compounds from plant extracts. Malaria Journal, United Kingdom, v.10, n.1, S.5, 2011.

DI STASI, L.C.; HIRUMA, C.C.; GUIMARÃES, E.M.; SANTOS, C.M. Medicinal plants popularly used in Brazilian Amazon. Fitoterapia, Milano, v.5, n.6, p.529-540, 1994 apud MILLIKEN,1997b.

DUKE, J.; VÁSQUEZ, R.V. Amazonian Ethnobotanical dictionary. Boca Raton: CRC Press, 1994. 215p.

FASIHUDDIN B.A.; GHAZALLY, I. Medicinal plants used by Kadazandusun communities around Crocker range. Asian Review of Biodiversity and Environmental Conservation. 2003. Disponível em: $<$ http://www.arbec.com.my/pdf/artljanmar03.pdf $>$. Acesso em: 20 dez. 2012.

FERNÁNDEZ, C. Plantas comestibles de Centroamérica. Santo Domingo de Heredia: Instituto Nacional de Biodiversidad, 2009. 360p.

FISCHER，D.C.H.; GUALDA，N.C.A.; BACHIEGA, D.; CARVALHO, C.S.; LUPO, F.N.; BONOTTO, S.V.; ALVES, M.O.; YOGI, A.; DI SANTI, S.M.; AVILA, P.E.; KIRCHGATTER, K; HRIHOROWITSCH, P.R.M. In vitro screening for antiplasmodial activity of isoquinoline alkaloids from Brazilian plant species. Acta Tropica, Miami, v.92, n.3, p.261-266, 2004.
GARAVito, G., RINCÓN, J., ARTEAGA, L., HATA, Y., BOURDY, G., GIMENEZ, A.; PINZÓN, R.; DEHARO, E. Antimalarial activity of some Colombian medicinal plants. Journal of Ethnopharmacology, Limerick, v.107, p.460-462, 2006.

GATHIRWA, J.W.; RUKUNGA, G.M; MWITARI, P.G; MWIKWABE, N.M; KIMANI, C.W; MUTHAURA, C.N; KIBOI, D.M; NYANGACHA, R.M; OMAR, S.A. Traditional herbal antimalarial therapy in Kilifi district, Kenya. Journal of Ethnopharmacology, Lausanne, v.134, n.2, p.43442, 2011.

GBEASSOR, M., KEDJAGNI, A.Y., KOUMAGLO, K.; SOUZA C., AGBO, K.; AKLIKOKOU, K.; AMEGHO, K.A. In vitro antimalarial activity of six medicinal plants. Phytotherapy Research, London, v.4, n.3, p.115-117,1990 apud MILLIKEN, 1997b.

GÓMEZ-ESTRADA, H.; DÍAZ-CASTILLO, F.; FRANCO-OSPINA, L.; MERCADO-CAMARGO, J.; GUZMÁN-LEDEZMA, J.; MEDINA., J.; GAITÁN-IBARRA, R. Folk medicine in the northern coast of Colombia: an overview. Journal of Ethnobiology and Ethnomedicine, London, v.7, n.27, 2011. Disponível em: <www.ethnobiomed. com/content/7/1/27>.

GÓMEZ-ESTRADA，H.; GERMOSÉNROBINEAU, L.; NOSSIN, E. Estudio etnofarmacológico de las plantas medicinales usadas en el Caribe colombiano. In: LISET, G.; SÁNCHEZ, R. Diálogo de saberes: plantas medicinales, salud y cosmovisiones. Bogotá: Universidad Nacional de Colombia, Sede Amazonia; ARFO Editores e Impresos, 2009. p. 135-156.

GRENAND, P.; MORETTI C.; JACQUEMIN, $\mathrm{H}$. Pharmacopées traditionnelles en Guyane. Marseille: IRD ORSTOM, 1987. 569 p.

HECKEL, E. Les plantes médicinales et toxiques de la Guiane Française acon. France, 1897 apud MILLIKEN, 1997b.

HIDALGO, A.F. Plantas de uso popular para o tratamento da malária e males associados da área de influência do rio Solimões e região de Manaus - AM. 2003. 202 f. Tese (Doutorado) - Faculdade de Ciências Agronômicas - Universidade Estadual Paulista, 2003. 
HODGE, W.H.; TAYLOR. D. The ethnobotany of the Island Caribs of Dominica .Economic Botany, Lawrence v.12, n.2, p.513-644, 1957 apud MILLIKEN, 1997b.

HOUT, S.; CHEA, A.; BUN, S.; ELIAS, R.; GASQUET, M.; TIMON-DAVID, P.; BALANSARD, G.; AZAS, N. Screening of selected indigenous plants of Cambodia for antiplasmodial activity Sotheara. Journal of Ethnopharmacology, Limerick, v.107, p.12-18, 2006.

ICHINO, C.; SOONTHORNCHAREONNON, N.; CHUAKUL, W.; KIYOHARA, H.; ISHIYAMA, A.; SEKIGUCHI, H.; NAMATAME, M.; OTOGURO, K.; OMURA, S.; YAMADA, H. Screening of thai medicinal plant extracts and their active constituents for in vitro antimalarial activity. Phytotherapy Research, London, v.20, n.4, p.307-309, 2006.

JOY, P.P.; THOMAS, J.; MATHEW, S.; BABY P. SKARIA. Medicinal Plants. Kerala Agricultural University Aromatic and Medicinal Plants Research Station, 1998. Disponível em: $\leq$ http:// www.armchairpatriot.com/HardCorePrepper/ Medicinal\%20Plants.pdf $>$. Acesso em: 12 out. 2012.

KAOU, M.,A.; MAHIOU-LEDDET, V.; HUTTER, S.; INOUDDINE, S.A., HASSANI, S.; YAHAYA, I.; AZAS, N.; OLLIVIER, E. Antimalarial activity of crude extracts from nine African medicinal plants. Journal of Ethnopharmacology, Limerick, v.116, p.74-83, 2008.

KIMBI, H.K.; FAGBENRO-BEYIOKU, A.F. Efficacy of Cymbopogon giganteus and Enantia chlorantha against chloroquine-resistant Plasmodium yoelii nigeriensis. East African Medical Journal, Kenya, v.73, n.10, p.636-637, 1996.

KONADU, K. Indigenous medicine and knowledge in African society. London: Routledge, 2007. 240 p.

KOUDOUVO, K.; KAROU, D.S.; KOKOU, K.; ESSIEN, K.; AKLIKOKOU, I.A.; GLITHO, SIMPORE, J.; SANOGO, R.; SOUZA, J.; GBEASSOR., M. An ethnobotanical study of antimalarial plants in Togo Maritime Region. Journal of Ethnopharmacology, Limerick, v.134, p.183-190, 2011.
KRIEF, S.; HUFFMAN, M.A.; SEVENET, T.; HLADIK, C.; GRELLIER, P.; LOISEAU, P.M.; WRANGHAM, R. Bioactive properties of plant species ingested by chimpanzees (Pan troglodytes schweinfurthii) in the Kibale National Park, Uganda. American Journal of Primatology, New York, v.68, n.1, p.51-71, 2006.

KULIP, J. An ethnobotanical survey of medicinal and other useful plants of Muruts in Sabah, Malaysia. Telopea, Wales, v.10, n.1, p.81-98, 2003

KUMARI, P.; GOPAL S.S. Ethnobotanical study of medicinal plants used by the Taungya community in Terai Arc Landscape, India. Journal of Ethnopharmacology, Limerick, v.123, p.167-176, 2009.

LANNUZEL, A.; MICHEL, P.P; CAPARROSLEFEBVRE, D.; ABAUL, J.; HOCQUEMILLER, R.; RUBERG, M. Toxicity of Annonaceae for dopaminergic neurons: potential role in atypical Parkinsonism in Guadeloupe. Movement Disorders, Washington, v.17, p.84-90, 2002.

LANNUZEL, A.; MICHEL, P.P.; HÖGLINGER G.U.; CHAMPY, P.; JOUSSET, A.; MEDJA, F.; LOMBÈS, A.; DARIOS, F.; GLEYE, C.; LAURENS, A.; HOCQUEMILLER, R.; HIRSCH, E.C.; RUBERG, M. The mitochondrial complex I inhibitor annonacin is toxic to mesencephalic dopaminergic neurons by impairment of energy metabolism. Neuroscience, Oxford, v.121, n.2, p.287-296, 2003.

LEAMAN, D.J.; ARNASON, J.T.; YUSUF, R.; SANGAT-ROEMANTYO, H.; SOEDJITO, H.; ANGERHOFER, C.K.; PEZZUTO, J.M. Malaria remedies of the Kenyah of the Apo Kayan, East Kalimantan, Indonesian Borneo: A quantitative assessment of local consensus as an indicator of biological efficacy. Journal of Ethnopharmacology, Orlando, v.49, p.1-16, 1995.

LEKANA-DOUKI, J.B.; BONGUI, J.B.; OYEGUE LIABAGUI, S.L.; ZANG EDOU, S.E.; ZATRA, R.; BISVIGOU, U.; DRUILHE, P.; LEBIBI, J.; TOURE NDOUO, F.S.; KOMBILA, M.M. In vitro antiplasmodial activity and cytotoxicity of nine plants traditionally used in Gabon. Journal of Ethnopharmacology, Orlando, v.133, p.1103-1108, 2011. 
LONGUEFOSSE, J. L. Plantes médicinales de la Caraïbe. Trinité: Gondwana Editions, 2003. v.2.

MABBERLEY, D.J. Plant-book. $3^{\text {rd }}$ ed. Cambridge: Cambridge University Press, 2008. 1021p.

MÉNAN, H.; BANZOUZI, J.T.; HOCQUETTE, A.; PÉLISSIER, Y.; BLACHE, Y.; KONÉ, M.; MALLIÉ, M.; ASSI, L.A.; VALENTIN, A. Antiplasmodial activity and cytotoxicity of plants used in West African traditional medicine for the treatment of malaria. Journal of Ethnopharmacology, Orlando, v.105, p.131-136, 2006.

MESQUITA, M.L.; GRELLIER, P.; MAMBU L.; PAULA J.E.; ESPINDOLA, L.S. In vitro antiplasmodial activity of Brazilian Cerrado plants used as traditional remedies. Journal of Ethnopharmacology, Orlando, v.110, p.165-170, 2007.

MILLIKEN, W. Traditional anti-malarial medicine in Roraima, Brazil. Economic Botany, Lawrence, v.51, n.3, p.212-237, 1997a.

MILLIKEN, W. Plants for malaria. Plants for fever. Medicinal species in Latin America - a bibliographic survey. United Kingdom: Whitsrable Litho, 1997b. p.116.

MONTES GIRALDO, J.J. Vegetales y otras sustancias usadas como remedies. Bogotá: Instituto Caro y Cuervo, 1981 apud MILLIKEN, 1997b.

MORS, W.B.; RIZZINI, C.T.; PEREIRA, N.A. Medicinal plants of Brazil. Algonac: Reference Publications, 2000. 501p.

MORTON, J. F. Atlas of medicinal plants of Middle America. C.C. Thomas, Springfield, Ill, 1981. 1420 p. apud MILLIKEN, $1997 \mathrm{~b}$.

MUGANZA, D.M.; FRUTH, B.I.; LAMI, J.N.; MESIA, G.K.; KAMBU, O.K.; TONA, G.L.; KANYANGA, R.C.; COS, P.: MAES, L.; APERS, S.; PIETERS, L. In vitro antiprotozoal and cytotoxic activity of 33 ethnopharmacologically selected medicinal plants from Democratic Republic of Congo. Journal of Ethnopharmacology, Limerick, v.141, p.301-308, 2012.
MUHAMMAD, I.; DUNBAR, D.C.; TAKAMATSU, S.; WALKER, L.A.; CLARK, A.M. Antimalarial cytotoxic and antifungal alkaloids from Duguetia hadrantha. Journal of Natural Products, Dawners Grove, v.64, p.559-562, 2001

MUTHAURA，C.N.; RUKUNGA，G.M.; CHHABRA, S.C.; MUNGAI, G.M.; NJAGI, E.N.Traditional antimalarial phytotherapy remedies used by the Kwale community of the Kenyan Coast. Journal of Ethnopharmacology, Limerick, v.114, p.377-386, 2007.

NADKARNI, K.M.; NADKARNI, A.K. (Ed.) Indian materia medica. $3^{\text {rd }}$ ed. Mumbai: Popular Prakashan Private, 1955. v.1, 115p

NDENECHO, N.E. Ethnobotanic resources of tropical montane forests: indigenous uses of plants in the Cameroon Highland ecoregion. Mankon Bamenda: African Books Collective, 2011. 230p.

NKUNYA, M.H.H.; WEENEN, H.; BRAY, D.H.; MGANI, Q.A.; MWASUMBI, L.B. Antimalarial activity of Tanzanian plants. 3. Antimalarial activity of Tanzanian plants and their active constituents: the genus Uvaria. Planta Medica, Antwerp, v.57, n.4, p.341-3, 1991 .

NOVY, J. Medicinal plants of the eastern region of Madagascar. Journal of Ethnopharmacology, Limerick, v.55, p. 119-126, 1997.

OBERLIES, N.H.; CROY, V.L.; HARRISON, M.L.; MCLAUGHLIN, J.L. The Annonaceous acetogenin bullatacin is cytotoxic against multidrug-resistant human mammary adenocarcinoma cells. Cancer Letters, Oxford, v.115, p.73-9, 1997.

OCAMPO, D.S.; OCAMPO, C. Bioactividad de la familia Annonaceae. Revista Universidad de Caldas, Colombia, p.135-155, 2006.

ODUGBEMI, T. A. textbook of medicinal plants from Nigeria. Nigeria: University of Lagos Press, 2008. 588p.

OKPEKON, T.; YOLOU, S.; GLEYE, C.; ROBLOT, F.; LOISEAU, P.; BORIES, C.; GRELLIER, P.; FRAPPIER, F.; LAURENS, A.; HOCQUEMILLER, R. Antiparasitic activities of medicinal plants used in Ivory Coast. Journal of Ethnopharmacology, Limerick, v.90, p.91-97, 2004. 
PIO CORRÊA, M. Dicionário das plantas úteis do Brasil e das exóticas cultivadas. Rio de Janeiro: Imprensa Nacional, 1926-1978. v. 1-6, 646p.

PONTES, W.J.; OLIVEIRA, J.C.S.; CÂMARA, C.A.G.; GONDIM JÚNIOR, M.G.C.; OLIVEIRA, J.V.; SCHWARTZ, M.O.E. Atividade acaricida dos óleos essencias de folhas e frutos de Xylopia sericea sobre o ácaro rajado (Tetranychus urticae Koch). Química Nova, São Paulo, v.30, n.4, p. 838-841, 2007.

RAIBURN, D. Let's get natural with herbs: the most complete A-Z reference guide to utilizing herbs for health and beauty. Madison: Okzar Mountain Publishing, 2007.

RUPPRECHT, J.K.; HUI, Y.H.; MCLAUGHLIN, J.L. Annonaceous acetogenins: a review. Journal of Natural Products, Dawners Grove, v.53, p. 237-278, 1990.

RUTTER, R.A. Catálogo de plantas utiles de la Amazonia Peruana. Peru: Instituto Linguístico de Verano, Pucallpa, 1990 apud MILLIKEN, 1997b.
SAFFORD, L.; MALTBY, E. Guidelines for integrated planning and management of tropical lowland peatlands: with special reference to Southeast Assia. United Kingdom: IUCN, 1998.

SCHULTES, R.E.; RAFFAUF, R.F. El bejuco del alma, los médicos tradicionales de la Amazonia Colombiana, sus plantas y rituales. Antioquia: Banco de la República: Ediciones Uniandes y Editorial Universidad de Antioquia, 1994. 284 p.

TSABANG, N.; FOKOU, P.V.; TCHOKOUAHA, L.R.; NOGUEM, B.; BAKARNGA-VIA I.; NGUEPI, M.S.; NKONGMENECK, B.A.; BOYOM, F.F. Ethnopharmacological survey of Annonaceae medicinal plants used to treat malaria in four areas of Camerron. Journal of Ethnopharmacology, Limerick, v.139, n.1, p.171-180, 2011. 